\title{
Assignment of "Achromobacter iophagus" Strain I.029 to Vibrio alginolyticus Chemovar iophagus
}

\author{
ISTVAN EMOD,${ }^{1}$ PASCAL SOUBIGOU,${ }^{1}$ NGUYEN T. TONG,${ }^{1}$ BORIVOJ KEIL,,${ }^{1 *}$ AND CLAUDE \\ RICHARD ${ }^{2}$ \\ Unite de Chimie des Proteines ${ }^{1}$ and Service des Enterobacteries, ${ }^{2}$ Institut Pasteur, 75015, Paris, France
}

\begin{abstract}
Strain CIP 82.01 of Vibrio alginolyticus and strain I.029 (previously designated "Achromobacter iophagus") were compared. Strain I.029 produces a collagenase of high specific activity (Achromobacter collagenase; EC 3.4.24.8). Collagenase production is induced in strain CIP 82.01 by collagen or macromolecular fragments of collagen in a manner similar to collagenase induction in strain I.029; caseinolytic proteinase is constitutive. In this study we demonstrate that both strains also produce a constitutive extracellular endonuclease. Collagenases from both strains cleave either native collagen in its helical region or a similar synthetic peptide; both enzymes are inhibited by ethylenediamine tetraacetate, but not by diisopropyl fluorophosphate. The collagenase subunit (molecular weight, 35,000) of strain CIP 82.01 is similar in amino acid composition to the subunit of the strain I.029 enzyme, although some of the aspartic and threonine residues in strain CIP 82.01 are replaced by glutamic and serine residues in strain I.029. Surface radioiodination followed by two-dimensional electrophoresis showed that there are quantitative differences in the major outer membrane proteins of the two strains. Strains CIP 82.01 and I.029 differ qualitatively in resistance to ampicillin and carbenicillin, in cellobiose fermentation, in ornithine decarboxylase activity, and in halophilism. We propose that strain I.029, which was originally designated $A$. iophagus, be included within the species $V$. alginolyticus, but that this organism be distinguished from other strains of this species by the designation Vibrio alginolyticus chemovar iophagus, with the corresponding collagenase designated "iophagus collagenase" (EC 3.4.24.8).
\end{abstract}

In 1973, Welton and Woods isolated and described the gram-negative aerobic bacterium Achromobacter iophagus (34). In the presence of collagen or macromolecular fragments of collagen (15), a subculture of this organism (strain I.029) produces a collagenase having a very high specific activity $(12,20)$. The structural and functional properties of this Achromobacter collagenase (EC 3.4.24.8), as well as the metabolism of strain I.029, have been described in a series of papers by Woods et al. $(21,26,27,29$, $35)$ and by workers in our laboratory $(4,10,11$, $13,14,19,30$ ).

In a recent study (27), which confirmed the original observation of collagenase induction by macromolecular collagen fragments (15), Achromobacter iophagus was reclassified as a strain of Vibrio alginolyticus; however, a direct experimental comparison of strain I.029 with a welldefined wild-type strain of $V$. alginolyticus has been lacking. It is well established that the other strains of the Vibrionaceae $(23,31)$ can be induced (by collagen and fragments of collagen) to produce collagenolytic and gelatinolytic enzymes.
We undertook a comparative study to determine the differences between strain I.029 isolated from a random selection of cured hides in South Africa (34) and a wild-type strain (strain CIP 82.01) of $V$. alginolyticus from a different geographical location (Madagascar) (28). Our results suggest that although $V$. alginolyticus CIP 82.01 from Madagascar and strain I.029 can be considered two strains of the same species, distinct biochemical differences do exist.

\section{MATERIALS AND METHODS}

Abbreviations. SDS, Sodium dodecyl sulfate; EDTA, ethylenediaminetetraacetic acid; Tris, tris(hydroxymethyl)aminomethane; $\mathrm{Pz}$, phenylazobenzyloxycarbonyl; ASF, partial peptic hydrolysate of collagen.

Strains, media, and growth conditions. Strain $\mathrm{I} .029$ (Collection Institut Pasteur, Paris, France) is a subculture of the microorganism originally described as " $A$. iophagus" by Welton and Woods (34). Strain CIP 82.01 (Collection Institut Pasteur, Paris) of $V$. alginolyticus was isolated from a coastal seabed sediment in Madagascar and was identified by Richard and Lhuillier (28). Cells were grown with agitation and forced aeration (1.4 atmospheres [1.51 dyn $\left./ \mathrm{cm}^{2}\right]$ ) at $30^{\circ} \mathrm{C}$ in 
$0.1 \mathrm{M}$ Tris-hydrochloride (supplemented with $0.4 \mathrm{M}$ $\mathrm{NaCl}$ and $2 \mathrm{mM} \mathrm{CaCl}$; $\mathrm{pH} \mathrm{7.6)}$ containing either $2.5 \%$ Casamino Acids (Difco Laboratories, Detroit, Mich.) or $1.5 \%$ ASF (peptic fragments of calf skin collagen; average molecular weight, 7,000; Rousselot SA, Paris, France). For growth control, turbidity was measured by absorbance at $600 \mathrm{~nm}(1-\mathrm{cm}$ light path) in samples withdrawn at 1-h intervals.

Enzyme assays. Collagenolytic activity was measured colorimetrically as described by Wünsch and Heidrich (36), using Pz-Pro-Leu-Gly-Pro-D-Arg (Fluka, Buchs, Switzerland) as the substrate. The results are expressed in nanokatals (nkat; 1 nkat $=1$ nmol of substrate per $\mathrm{s}=90 \mathrm{U}$, according to Wünsch and Heidrich [36]). Degradation of native calf skin collagen by purified collagenase was measured by changes in the negative Cotton effect monitored at 215 $\mathrm{nm}$ by optical rotatory dispersion, as described by Keil et al. (11). Collagen (calf skin; type III; Sigma Chemical Co., St. Louis, Mo.) was dissolved in $50 \mathrm{mM}$ Trishydrochloride buffer supplemented with $5 \mathrm{mM} \mathrm{CaCl}_{2}$ and $0.4 \mathrm{M} \mathrm{NaCl}(\mathrm{pH} \mathrm{7.6)}$ to a final concentration of $1.86 \mathrm{mg} / \mathrm{ml}$. Changes in residual specific rotation were measured with an ORD apparatus (FICA, Paris, France) at $30^{\circ} \mathrm{C}$ in a $3-\mathrm{ml}$ cuvette.

Neutral proteinases were evaluated spectrophotometrically by using casein (E. Merck AG, Darmstadt, West Germany) as the substrate (18). Endonuclease activity was measured by the method of Kunitz (17); substrate deoxyribonucleic acid and deoxyribonuclease were purchased from Boehringer, Mannheim, West Germany.

Collagenase purification. The culture medium was concentrated, and the collagenase was purified as described previously $(12,20)$. After centrifugation, a culture supernatant was concentrated at $4^{\circ} \mathrm{C}$ by ultrafiltration, and the resulting concentrate was applied to a column of DE-32 cellulose (Whatman). Collagenasecontaining fractions obtained by gradient elution were stabilized by adding $0.1 \mathrm{M}$ histidine, concentrated by ultrafiltration (type UM-10 membrane; Amicon Corp., Lexington, Mass.) and lyophilized. The collagenase was then rechromatographed on DE-32 cellulose, dialyzed, and lyophilized.

Molecular weight and amino acid analyses. Molecular weights were estimated by SDS-polyacrylamide electrophoresis, using the method of Ames (1). Samples were denatured by heating them in a boiling bath $1 \% 2$ mercaptoethanol for $3 \mathrm{~min}$; elution was performed with $25 \mathrm{mM}$ Tris-hydrochloride- $0.2 \mathrm{M}$ glycine buffer (pH 8.3) supplemented with $1 \%$ SDS.

Amino acid analyses were performed fluorimetrically by using a modified automatic amino acid analyzer (Locarte Co., London, Great Britain) and $o$-phthalaldehyde (2). Proteins were hydrolyzed under a vacuum for $24 \mathrm{~h}$ in $6 \mathrm{~N} \mathrm{HCl}$ at $110^{\circ} \mathrm{C}$.

Inhibition assays. Solutions of enzyme in $0.1 \mathrm{M}$ Trishydrochloride buffer $(\mathrm{pH} \mathrm{7.0)}$ were incubated in presence of inhibitors for $1 \mathrm{~h}$ at $20^{\circ} \mathrm{C}$.

Radioiodination and sample solubilization. To assure a correct comparison of the two strains, the outer membrane proteins were radioiodinated under rigorously identical conditions, as described previously in a study dealing with strain I.029 (13). The lactoperoxidase-glucose-glucose oxidase iodination procedure was used (8), with the following modifications. A sample of a bacterial culture was diluted to a final absorbance of 5.0. Then $1 \mathrm{ml}$ of this diluted sample was centrifuged, and the resulting pellet was washed and suspended in $1.5 \mathrm{ml}$ of fresh medium containing $5.5 \mathrm{M}$ glucose. Then $10 \mu \mathrm{g}$ of glucose oxidase (228 $\mathrm{U} / \mathrm{mg}), 10 \mu \mathrm{g}$ of lactoperoxidase (67 U/mg; Sigma), and $1 \mathrm{mCi}$ of carrier-free $\mathrm{Na}^{125} \mathrm{I}(100 \mathrm{Ci} /$ liter; Amersham Corp., Arlington Heights, Ill.) were added. Iodination was performed at room temperature for 20 min with constant agitation. The reaction was stopped by adding $10 \mathrm{ml}$ of phosphate-saline buffer $(0.2 \mathrm{M}$ $\mathrm{NaCl}, 2.6 \mathrm{mM} \mathrm{KCl}, 3.2 \mathrm{mM} \mathrm{Na} \mathrm{HPO}_{4}, 1.4 \mathrm{mM}$ $\mathrm{KH}_{2} \mathrm{PO}_{4}, \mathrm{pH} 7.4$ ) containing $0.15 \mathrm{M}$ unlabeled $\mathrm{KI}$, and the suspension was then centrifuged at $12,000 \times g$ for $10 \mathrm{~min}$. After the resulting pellet was washed in the same buffer, it was dissolved in $100 \mu$ l of lysis buffer containing $9.5 \mathrm{M}$ urea, $2 \%$ (wt/vol) Nonidet P-40, $2 \%$ (vol/vol) ampholines ( $\mathrm{pH}$ range, 4 to 6; Servalyt), and $5 \%$ (vol/vol) 2-mercaptoethanol.

Two-dimensional polyacrylamide gel electrophoresis. The procedure of O'Farrell (24) was modified as described below.

For the first-dimension separation by isoelectric focusing, gels $(0.25$ by $10.5 \mathrm{~cm})$ were prepared by using ampholines with a $\mathrm{pH}$ range of 4 to 6 . A sample was loaded onto each gel, and the gels were run at 300 $\mathrm{V}$ overnight. Then the gels were equilibrated for 30 $\min$ in $10 \mathrm{ml}$ of buffer containing $62.5 \mathrm{mM}$ Trishydrochloride ( $\mathrm{pH} 6.8$ ), $10 \%$ glycerol, 5\% SDS, 5\% 2mercaptoethanol, and $0.1 \%$ bromophenol blue. For separation in the second dimension on SDS-polyacrylamide gels, the following molecular weight marker proteins were applied to each gel: phosphorylase $b$ (molecular weight, 96,000), bovine serum albumin $(68,000)$, aldolase (subunit) $(40,000)$, and chymotrypsinogen $(25,000)$. Electrophoresis was performed at a constant current of $40 \mathrm{~mA} / \mathrm{gel}$.

Gels were stained with Coomassie brilliant blue and destained in $45 \%$ methanol-10\% acetic acid. The dried gels were exposed to Kodak X-ray film.

Immunochemical assays. Antibodies against pure collagenase from strain I.029 were a gift from V. KeilDlouha. For the double-diffusion assay (25), we used a solution containing $1 \mathrm{mg}$ of collagenase per $\mathrm{ml}$. Immunoelectrophoresis (5) was performed in a slab (length, $9 \mathrm{~cm}$ ) of $1 \%$ agar gel in $5 \mathrm{mM}$ Veronal buffer ( $\mathrm{pH} \mathrm{8.2)}$; the electrode buffer was $50 \mathrm{mM}$ Veronal. Samples were run for $45 \mathrm{~min}$ at $80 \mathrm{~V}$.

\section{RESULTS}

Bacteriology of $V$. alginolyticus strains. Both strain CIP 82.01 and strain I.029 are aerobic or facultatively anaerobic, gram-negative, rodshaped bacteria (length, 2 to $2.5 \mu \mathrm{m}$; width, 1 to $1.5 \mu \mathrm{m})$ that are motile by means of a simple polar flagellum. They form round, yellow colonies that are 2 to $3 \mathrm{~mm}$ in diameter after overnight incubation at $30^{\circ} \mathrm{C}$ on thiosulfate-citratebile-sucrose medium.

Both strains produce positive responses in the following assays: cytochrome oxidase; VogesProskauer reaction; indole production; lysine decarboxylase; gelatinase (film assay); Tween 80 esterase; tetrathionate reductase; nitrate reduction; acid production from glucose, maltose, 


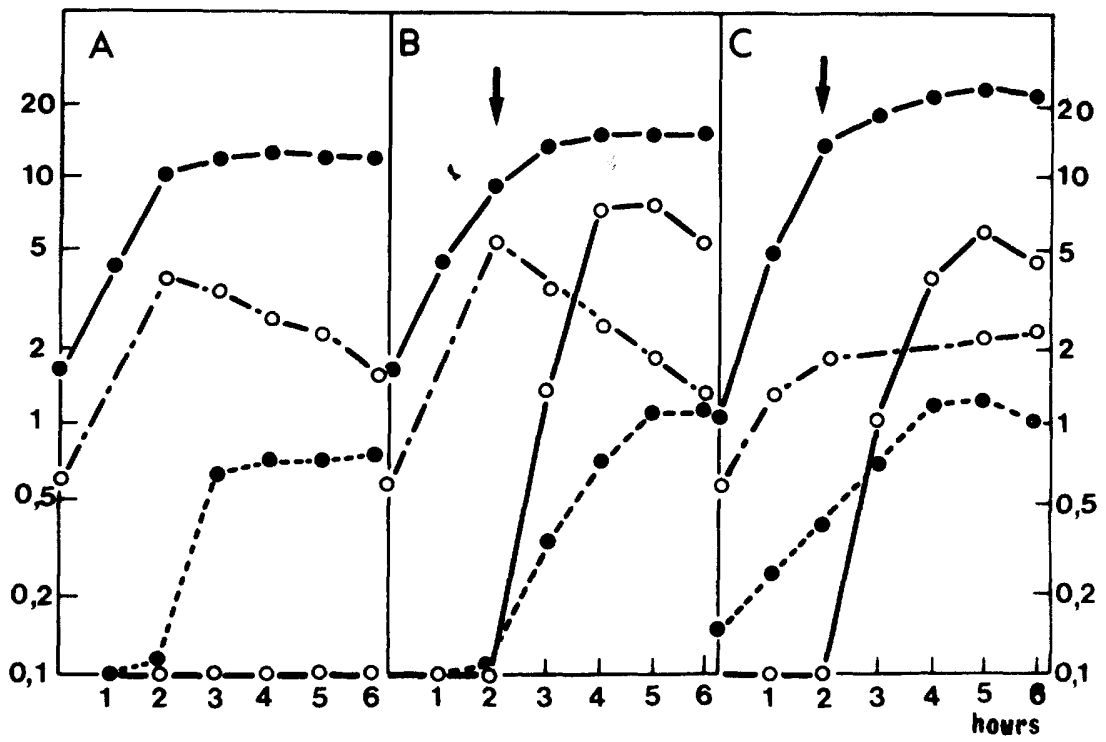

FIG. 1. Cell growth and enzyme production by $V$. alginolyticus strains. The abscissa indicates time (in hours), and the ordinate indicates the amount of growth and the results of three enzyme tests (see below). (A) Strain CIP 82.01, noninduced. (B) Strain CIP 82.01, induced. (C) Strain 1.029, induced. The arrows indicate when an inducer was added. Symbols: - - , growth, as measured by optical density at $600 \mathrm{~nm}$; $\bigcirc-\bigcirc$, amount of collagenase produced, as measured by a synthetic peptide assay (in microkats per milliliter, $\times 10^{-4}$ ); $-\ldots$....amount of proteinase produced as measured by the caseinolytic assay (in micrograms of trypsin per milliliter, $\left.\times 10^{-1}\right)$; $\bigcirc-\ldots . . .-$, amount of endonuclease produced, as measured by the deoxyribonucleic acid assay (in micrograms of deoxyribonucleic acid equivalents, $\times 10^{-2}$ ).

mannitol, sucrose, trehalose, mannose, and glycerol; and citrate (Simmons) utilization. As determined by the disk assay, they are both susceptible to aminoglycosidic antibiotics, chloramphenicol, tetracycline, colistin, rifampin, sulfonamides, nalidixic acid, nitrofurantoin, and vibriostatic agent O/129 (2,4-diamino-6,7diisopropylpteridine phosphate). Both strains are resistant to trimethoprim.

Both strains give negative responses in the following assays: methyl red reaction; arginine dihydrolase; urease; phenylalanine deaminase; $o$-nitrophenyl- $\beta$-D-galactopyranoside assay; $\mathrm{H}_{2} \mathrm{~S}$ production (Kligler iron agar); glucose gas production; and acid production from xylose, arabinose, adonitol, rhamnose, sorbose, sorbitol, dulcitol, lactose, inositol, salicin, raffinose, mellibiose, $\alpha$-methylglucoside, and mucate. Neither strain utilizes malonate.

Strain I.029 is markedly more halophilic than strain CIP 82.01, with optimum growth occurring in $13 \% \mathrm{NaCl}$ and apparent tolerance to $15 \%$ $\mathrm{NaCl}$. Strain I.029 is also fully resistant to ampicillin and carbenicillin and partially resistant to cephalothin, antibiotics to which strain CIP 82.01 is susceptible. We also observed differences in the results of ornithine decarboxylase and cellobiose fermentation assays (nega- tive for strain CIP 82.01, but positive for strain I.029).

Nuclease, proteinase, and collagenase production. The two strains were grown either in medium containing 2.5\% Casamino Acids (Fig. 1A) or in the same medium for $2 \mathrm{~h}$ and then in medium to which ASF collagenase inducer was added to a final concentration of $1.5 \%$ (Fig. 1B and C). Both strains produced extracellular nuclease and caseinolytic proteinase independently of the presence of the inducer. In contrast, collagenase appeared in both cultures only when the medium contained ASF; after $3 \mathrm{~h}$ the collagenase level increased to $60 \mathrm{nkat} / \mathrm{ml}$ for strain I.029 and to $80 \mathrm{nkat} / \mathrm{ml}$ for strain CIP 82.01.

All three of the enzymes described above reached a maximum of activity, and then their levels decreased due to proteolysis. The samples used for isolation of collagenase were withdrawn at the point of maximum activity (Fig. 1B and C).

Differences in outer membrane proteins. Samples were withdrawn from the cultures during the exponential phase of growth (Fig. 2A and C) and after induction by ASF (Fig. 2B and D). Two independent experiments gave essentially identical results. We found an average of 15 major outer membrane proteins; these proteins 

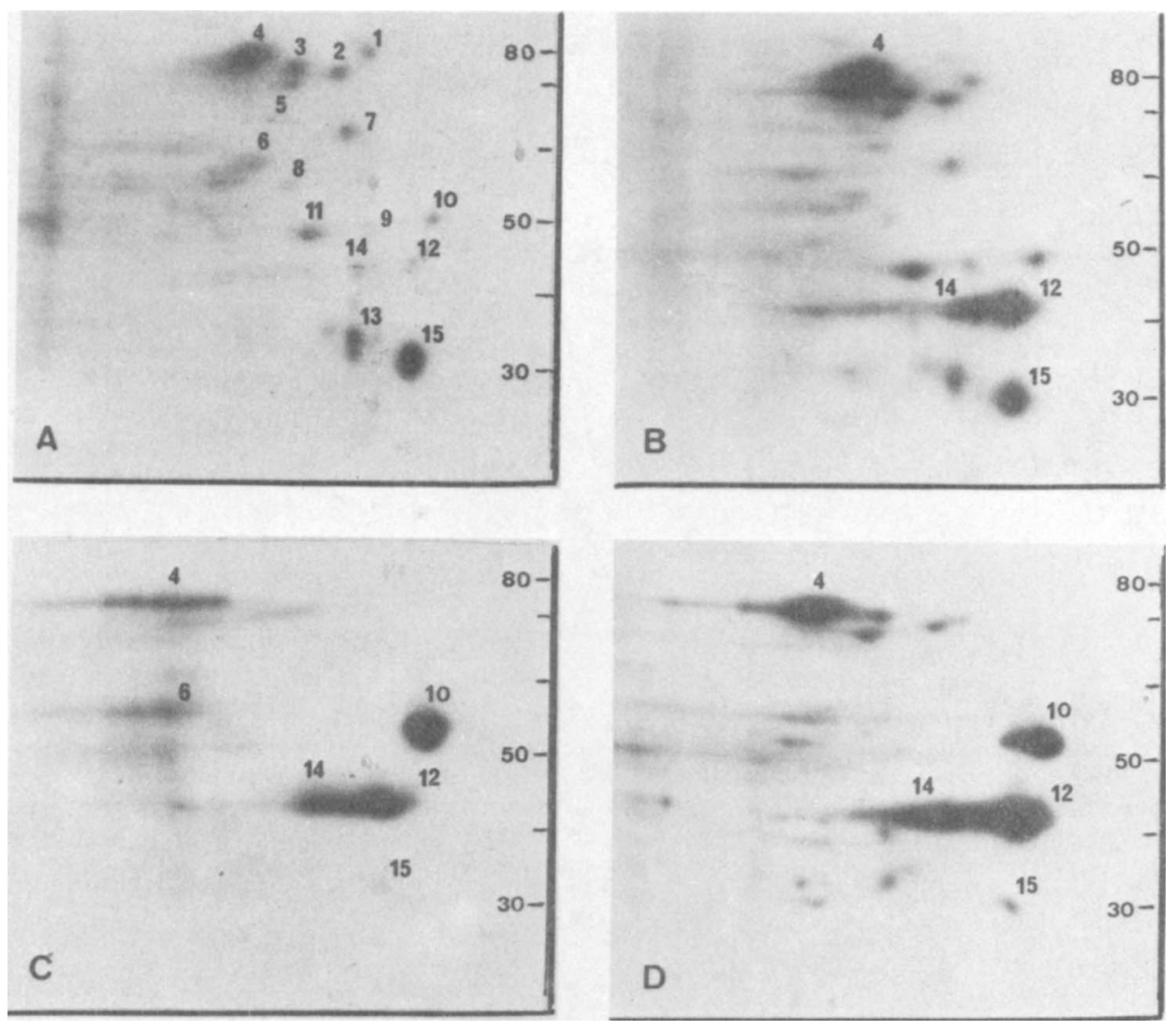

FIG. 2. Two-dimensional gel electrophoresis of major radioiodinated outer membrane proteins: strain I.029 before $(A)$ and after $(B)$ induction and strain CIP 82.01 before $(C)$ and after $(D)$ induction. The ordinate indicates molecular weights $\left(\times 10^{3}\right)$.

had isoelectric points at $\mathrm{pH} 5$ to 7 and molecular weights that varied from 30,000 to 90,000 . The differences in the patterns of these proteins are discussed below.

Purification of collagenase from $V$. alginolyticus strain CIP 82.01. Table 1 summarizes the yields obtained at intermediate steps of collagenase purification. The most important loss occurred during concentration of a dilute solution of the purified enzyme after chromatography on DE-32 cellulose (Fig. 3). The specific activity of the lyophilized enzyme on the peptide substrate was $0.7 \mu \mathrm{kat} / \mathrm{mg}$; after rechromatography, the activity increased to $1.1 \mu \mathrm{kat} / \mathrm{mg}$. Under identical conditions, purification of the collagenase from strain I.029 gave an enzyme specific activity of $1.8 \mu \mathrm{kat} / \mathrm{mg}$, which corresponds to the values obtained previously $(12,14)$.

Inhibition and specificity of the collagenase from strain CIP 82.01. After incubation in $10^{-2}$ $\mathrm{M}$ diisopropyl fluorophosphate for $1 \mathrm{~h}$ at $20^{\circ} \mathrm{C}$, the enzyme lost only $7.3 \%$ of its original activity; in contrast, it was completely inhibited by $10^{-2}$ M EDTA.
According to the optical rotatory dispersion assay (11), active collagenase degrades the helical structure of native collagen at a rate of 1.9 $\mathrm{mg} / \mathrm{min}$ per $\mathrm{mg}$ of enzyme (Fig. 4). When the synthetic peptide Pz-Pro-Leu-Gly-Pro-D-Arg was used, the strain CIP 82.01 collagenase cleaved the same bond (Leu-Gly) as the strain I.029 collagenase (11); the specific activity on this substrate was $1.1 \mu \mathrm{kat} / \mathrm{mg}$ ( $66 \mu \mathrm{mol} / \mathrm{min}$ per $\mathrm{mg}$ ).

TABLE 1. Purification of collagenase from the culture medium of $V$. alginolyticus CIP 82.01

\begin{tabular}{lrrr}
\hline \multicolumn{1}{c}{ Step } & $\begin{array}{c}\text { Total vol } \\
\text { or wt }\end{array}$ & $\begin{array}{c}\text { Total } \\
\text { activity } \\
(\mu \text { kat) }\end{array}$ & $\begin{array}{c}\text { Recovery } \\
(\%)\end{array}$ \\
\hline Culture medium & $3,100 \mathrm{ml}$ & 1,390 & 100 \\
Centrifugation & $2,900 \mathrm{ml}$ & 678 & 49 \\
Ultrafiltration & $110 \mathrm{ml}$ & 653 & 47 \\
Chromatography (DE-32) & $72 \mathrm{ml}$ & 564 & 40 \\
Concentration (UM-10) & $12 \mathrm{ml}$ & 58 & 4 \\
Lyophilization & $57 \mathrm{mg}$ & 40 & 3 \\
Rechromatography & $14 \mathrm{mg}$ & 16 & 1 \\
$\quad$ (DE-32) & & & \\
\hline
\end{tabular}




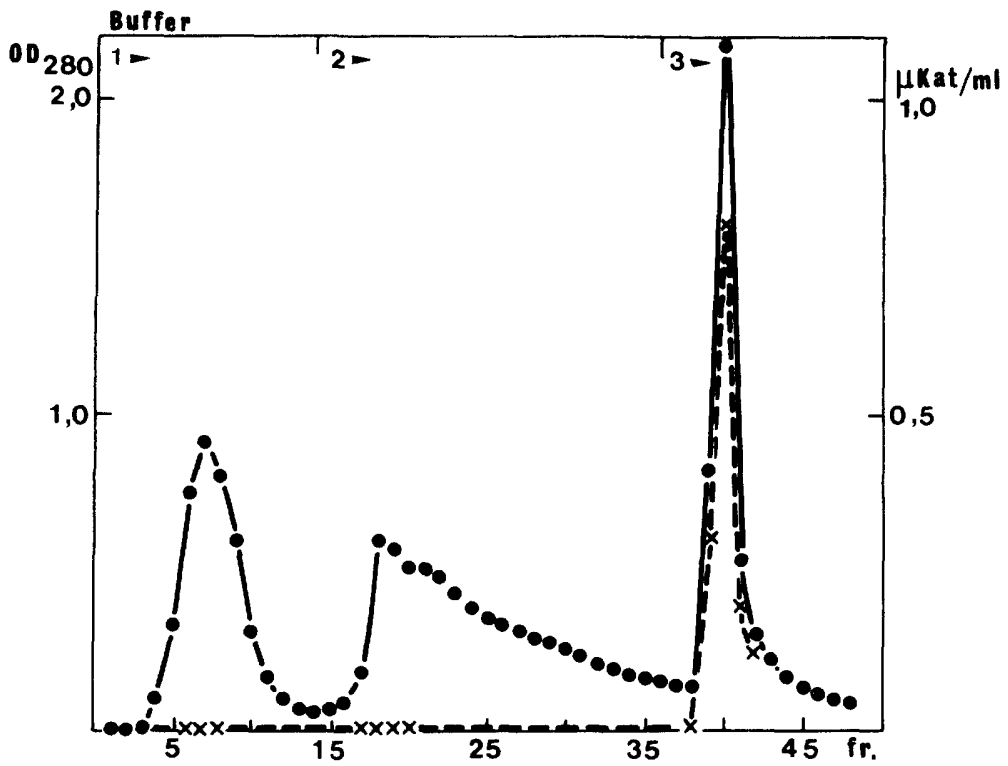

FIG. 3. Purification of collagenase from strain CIP 82.01 by cellulose DE-32 chromatography. The abscissa indicates the fraction (fr.) numbers. The column size was 10 by $2 \mathrm{~cm}$, and the flow rate was $1 \mathrm{ml} / \mathrm{min}$. The following buffers ( $\mathrm{pH}$ 7.0) were added: buffer 1, 0.2 M Tris-hydrochloride; buffer 2, $0.3 \mathrm{M}$ Tris-hydrochloride; buffer 3, 0.3 M Tris-hydrochloride-0.1 M histidine-1 M NaCl. Symbols: $O$, protein absorbance at $280 \mathrm{~nm}$ $\left(\mathrm{OD}_{280}\right) ; \times$, collagenase activity against Pz-Pro-Leu-Gly-Pro-D-Arg (in microkats per milliliter).

Molecular weight and amino acid composition of the collagenase subunit. On SDS-polyacrylamide electrophoresis gels, the collagenase from strain 1.029 gave one major band of dimeric enzyme (molecular weight, 70,000), a minor band of the enzyme-peptide complex (molecular weight, 80,000) (14), a subunit (molecular weight, 35,000), and traces of decomposition products (Fig. 5, lane B). The corresponding enzyme from strain CIP 82.01 gave more complex results (Fig. 5, lane A); apart from the appearance of major bands at molecular weights of 65,000 and 70,000 , the gel contained a number of bands from low-molecular-weight products that were indicative of deep degradation.

Collagenase from strain CIP 82.01 was dissociated by incubation with $10^{-2} \mathrm{M}$ EDTA, as described previously for strain I.029 collagenase (14). The products obtained after this treatment were separated by preparative slab gel electrophoresis. The major band at a molecular weight of 35,000 was electroeluted and subjected to reelectrophoresis (Fig. 5, lane C). The homogeneous band of the subunit was electroeluted, the protein was hydrolyzed, and the amino acid composition of the protein determined. In Table 2 the results of this analysis are compared with the amino acid compositions of the subunit of Achromobacter collagenase (strain I.029) (14), of thermolysin, and Bacillus subtilis neutral proteinase.
Immunochemical comparison. The collagenase from strain CIP 82.01 cross-reacted with antibodies against pure collagenase from strain I.029 in the Ouchterlony assay (Fig. 6A). We wanted to determine whether the minor components of collagenase revealed by SDS-polyacrylamide electrophoresis represented a mixture of heterogeneous proteins or degraded forms of the enzyme. Several bands resulting from immunoelectrophoresis of the same preparation crossreacted with the purified antibodies against pure strain I.029 collagenase (Fig. 6B).

\section{DISCUSSION}

Both strain I.029 and strain CIP 82.01 are in conformity with the taxonomic description of $V$. alginolyticus. However, these two strains differ in the following ways: resistance to beta-lactam antibiotics, cellobiose fermentation, ornithine decarboxylase activity, and tolerance to high saline concentrations. Optimum growth of strain I.029 occurs in the presence of $13 \% \mathrm{NaCl}$, and tolerance to $15 \% \mathrm{NaCl}$ has been observed, which suggests long evolutionary adaptation of an original marine organism to the high saline concentration of an inland sea.

Two-dimensional mapping of radioiodinated cell surface proteins allowed us to distinguish species and strain differences, as well as changes in membrane components under different phys- 


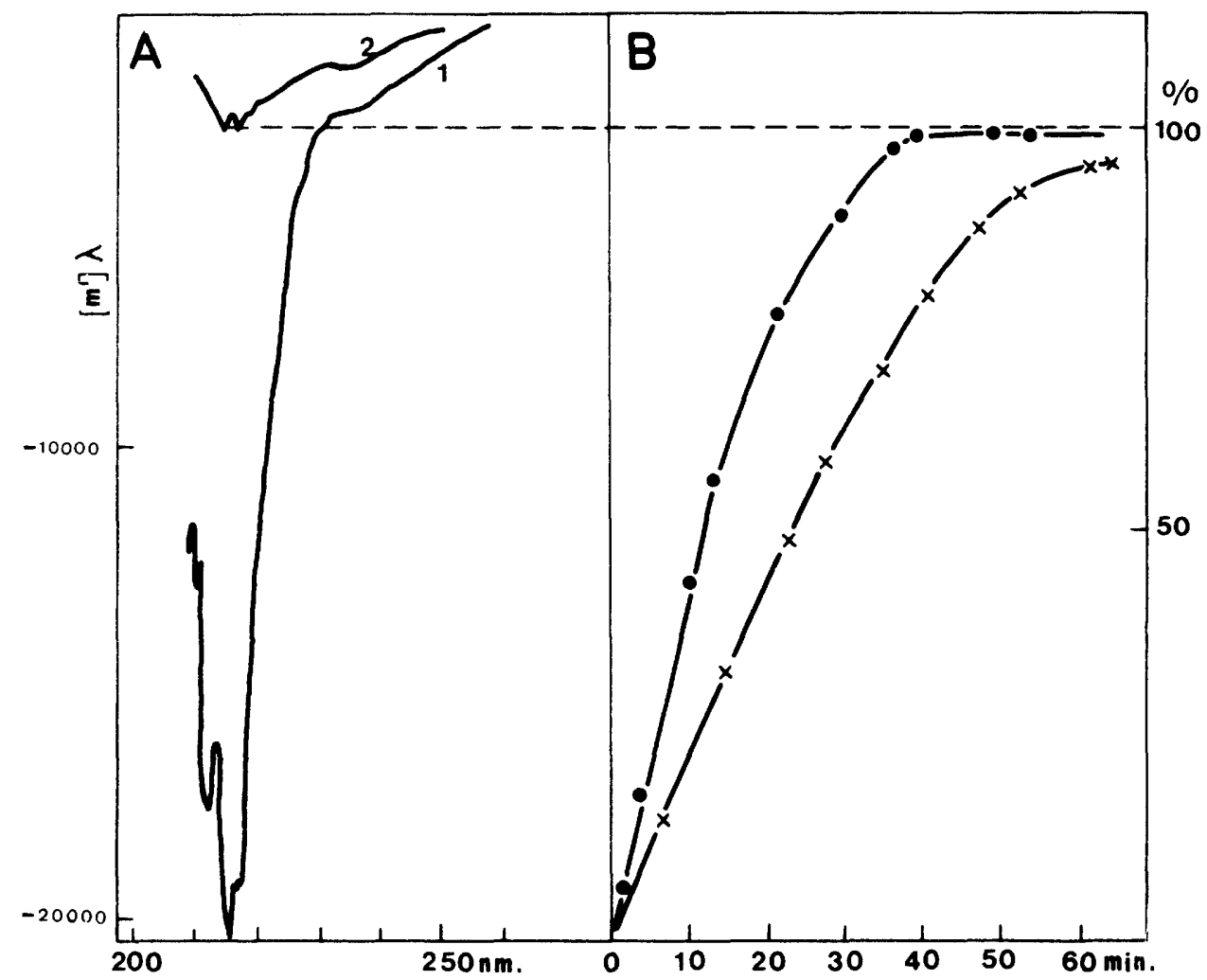

FIG. 4. Degradation of collagen by collagenases from strains CIP 82.01 and I.029, as determined by optical rotatory dispersion analysis. (A) Rotatory dispersion spectrum of native (line 1) and thermally denatured (line 2) collagen in the 205- to $250-\mathrm{nm}$ region of the scan. (B) Percent degradation of the helical structure of collagen at $215 \mathrm{~nm}$ by $7.5 \mathrm{nkat}$ of collagenase from strain CIP $82.01(\times)$ and by 3.3 nkat of collagenase from strain I.029 (O).

iological conditions. Thus, the patterns of outer membrane proteins accessible to iodination in the two strains examined in this study are qualitatively similar; however, we did observe reproducible quantitative differences (Fig. 2). In the exponential phase of growth and in the absence of inducer, proteins 10,12 , and 14 are predominant on the surface of strain CIP 82.01, whereas these proteins are minor proteins in strain I.029; in contrast, proteins $7,11,13$, and 15 of strain I.029 exist only in trace amounts in strain CIP 82.01.

The induction of collagenase by collagen or fragments of collagen has been observed previously in strain I.029 ("A. iophagus") (14), as well as in Vibrio parahaemolyticus (31) and Vibrio sp. strain B-30 (23). Our results show that $V$. alginolyticus strain CIP 82.01 also responds promptly to added inducer, with increased production of collagenase (Fig. 1B). Simultaneously, outer membrane protein 4 and particularly protein 12 (which is a major protein) become very prominent (Fig. $2 \mathrm{C}$ and $\mathrm{D}$ ). This effect is even more pronounced in strain I.029 (Fig. 2B). An independent study (13) demonstrated that surface protein 12 of this strain binds selectively to collagen, suggesting that it could represent a receptor protein for the inducer. The increase in the amount of protein 12 in both strains during induction indicates that regardless of the quantitative differences in the outer membrane proteins of strains CIP 82.01 and I.029, the induction mechanisms may follow similar pathways.

Observations of nuclease activity, which were made during preliminary bacteriological characterization of $V$. alginolyticus, prompted us to monitor extracellular endonuclease activity during culture of both strains (Fig. 1). This activity appears in the culture medium simultaneously with caseinolytic activity. The in vitro specificity of this response, as revealed with partially purified endonuclease from strain CIP 82.01, showed deep degradation of polymerized deoxyribonucleic acid; no restriction enzyme activity could be detected (R. Nageotte, unpublished data).

When the purification procedure used routinely for Achromobacter collagenase $(12,20)$ was used with strain CIP 82.01, less satisfactory results were obtained; although the activity in 


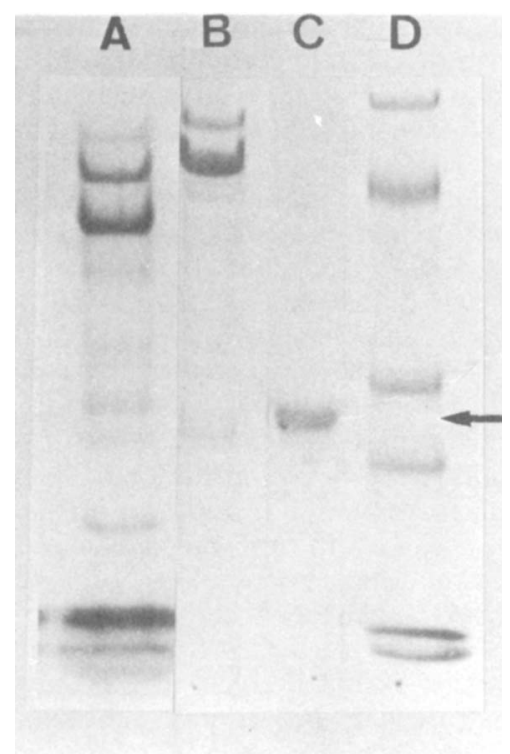

FIG. 5. SDS-polyacrylamide gel electrophoresis of collagenases. Lane A, Strain CIP 82.01; lane B, strain I.029; lane $C$, collagenase subunit from strain CIP 82.01 after re-electrophoresis; lane D, standard protein mixture (molecular weights, 96,000, 68,000, 40,000, and 25,000 ). The arrow indicates the subunit having a molecular weight of 35,000 .

the culture medium was high (Fig. 1B), the yield and the specific activity of the final enzyme product were low (Table 1). SDS-polyacrylamide gel electrophoresis of this product re- vealed two major components (molecular weights, 65,000 and 70,000) and a series of lowmolecular-weight fragments resulting from proteolytic degradation (Fig. 5, lane A).

The instability of bacterial collagenases, particularly in the latter stages of purification, is well known $(3,16,20)$. Multiple forms of the enzyme are produced by autolysis or by the action of other proteinases; homogeneous collagenase from Clostridium histolyticum can be isolated only when all traces of other proteinases, particularly clostripain, are removed (3), and strain I.029 produces simultaneously with collagenase a mixture of neutral proteinases $(15$, 20). Moreover, autolysis of collagenase in solution yields partially degraded and still enzymatically active forms, which differ in electrophoretic mobility (12). Thus, the relatively lower yield and homogeneity of the collagenase from strain CIP 82.01 compared with the collagenase from strain I.029 could be consequences of a higher concentration of the enzyme in the culture, of differences in the production of other proteinases by the particular strains, or of increased structural lability of the collagenase; experiments to answer these questions were outside the limits of this comparative study.

The collagenases from strains CIP 82.01 and I.029 degrade the helical region of native collagen; both cleave the same bond in the synthetic peptide Pz-Pro-Leu-Gly-Pro-D-Arg. The strain CIP 82.01 enzyme is not inhibited by $10^{-2} \mathrm{M}$ diisopropyl fluorophosphate, an irreversible inhibitor of serine proteinases. Since the collage-
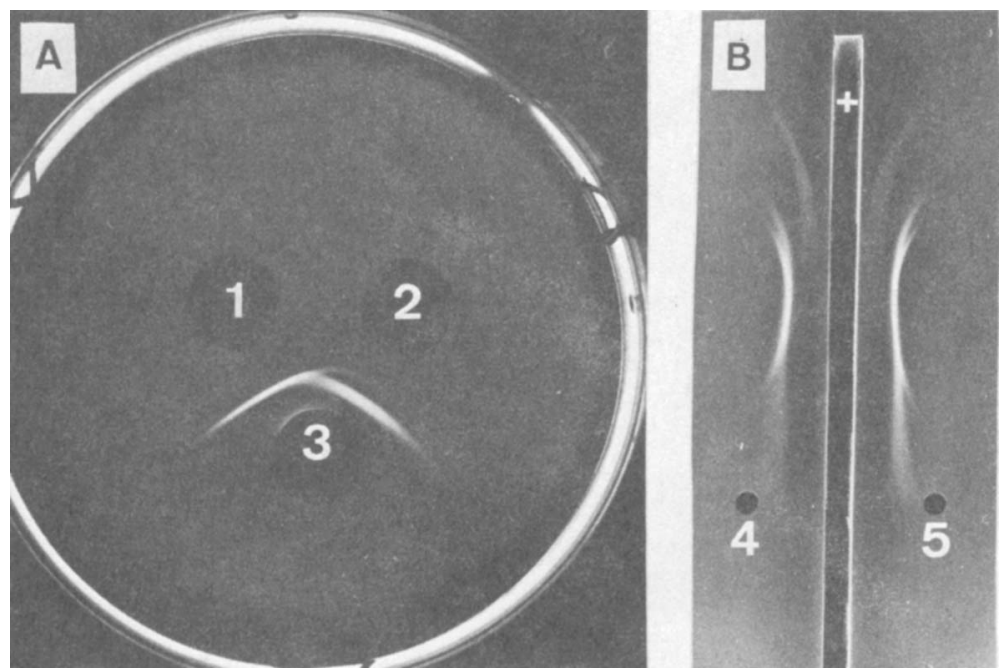

FIG. 6. Cross-reactivity of the collagenase from strain CIP 82.01 with antibodies against pure collagenase from strain I.029. (A) Ouchterlony assay. Well 1, Strain I.029 collagenase; well 2, strain CIP 82.01 collagenase; well 3, antibodies against strain I.029 collagenase. (B) Immunoelectrophoresis. The plus sign indicates the position of antibodies against strain 1.029 collagenase, and 4 and 5 indicate the positions of $2-$ and $4-\mathrm{mg} / \mathrm{ml}$ preparations of strain CIP 82.01 collagenase, respectively. For other details see the text. 
TABLE 2. Comparison of the amino acid compositions of collagenases from two $V$. alginolyticus strains, a thermolysin from $B$. thermoproteolyticus, and a neutral proteinase from B. subtilis

\begin{tabular}{lcccc}
\hline & \multicolumn{2}{c}{$\begin{array}{c}\text { Collagenase } \\
\text { from } V .\end{array}$} \\
$\begin{array}{l}\text { Amino } \\
\text { acid }\end{array}$ & $\begin{array}{c}\text { alginolyticus } \\
\text { strain: }\end{array}$ & $\begin{array}{c}\text { B. thermo- } \\
\text { proteo- } \\
\text { lyticus } \\
\text { thermol- } \\
\text { ysin }\end{array}$ & $\begin{array}{c}\text { B. subtilis } \\
\text { proteinase }\end{array}$ \\
\cline { 2 - 3 } & $\begin{array}{c}\text { CIP } \\
\text { 82.01 }\end{array}$ & I.029 & & \\
\hline Asx & 35.7 & 38 & 44 & 48 \\
Thr & 17.9 & 24 & 25 & 29 \\
Ser & 35.6 & 27 & 26 & 31 \\
Glx & 43.5 & 40 & 21 & 27 \\
Pro & ND & 7 & 8 & 9 \\
Gly & 27.0 & 27 & 36 & 30 \\
Ala & 26.0 & 26 & 28 & 28 \\
Half-Cys & ND & 4 & & \\
Val & 18.6 & 18 & 22 & 19 \\
Met & 3.0 & 3 & 2 & 4 \\
Ile & 14.0 & 14 & 18 & 13 \\
Leu & 23.8 & 25 & 16 & 21 \\
Tyr & 14.3 & 16 & 28 & 22 \\
Phe & 14.9 & 15 & 10 & 11 \\
Trp & ND & 8 & 3 & 3 \\
His & 8.0 & 8 & 8 & 5 \\
Lys & 10.6 & 11 & 11 & 17 \\
Arg & 8.1 & 9 & 10 & 8 \\
\hline
\end{tabular}

${ }^{a}$ Previously called Achromobacter collagenase. See reference 14.

${ }^{b}$ See reference 32.

${ }^{c}$ See reference 9.

${ }^{d}$ ND, Not determined.

nases from both strains are fully inhibited by EDTA, they should be considered metalloproteinases (EC 3.4.24). The similarities in the structures of the two enzymes are also shown by the fact that inactivation of strain CIP 82.01 collagenase by EDTA is followed by the appearance of a subunit having a molecular weight of 35,000 (Fig. 5, lane C), a process described previously for the Achromobacter (strain I.029) enzyme (14). The results of the immunochemical assays reported here demonstrate that the two collagenases contain a number of identical antigenic determinants (Fig. 6A and $\mathrm{B}$ ). The numerous bands of cross-reactivity shown by immunoelectrophoresis of strain CIP 82.01 collagenase with antibodies against strain I.029 collagenase suggest the presence of some partially degraded forms of the enzyme, in which the major determinants are conserved.

Previous studies have shown that the subunit of Achromobacter collagenase (strain I.029) may be structurally similar to the neutral proteinases recovered from Bacillus thermoproteolyticus (thermolysin; EC 3.4.24.4) and B. subtilis (10). This association is based on a comparison of molecular weights, amino acid compositions $(9$,
$14,32)$, essential components of the enzyme active sites $(7,33)$, and circular dichroism measurements (6). However, a comparison of the amino acid compositions of the purified subunits of strain CIP 82.01 and I.029 collagenases with the amino acid compositions of thermolysin and B. subtilis neutral proteinase (Table 2) indicates that the Vibrio collagenase preparations are very similar and differ somewhat from the proteinases. Some differences are apparent in the two Vibrio collagenases; higher levels of serine and glutamic acid (glutamine) residues in strain CIP 82.01 collagenase are compensated for by proportionally lower levels of threonine and aspartic acid (asparagine) residues in strain I.029 collagenase. This in turn indicates some differences in the primary structures of the polypeptide chains. Such genetically based structural differences in proteinases from different wildtype strains within a given species have been demonstrated in $B$. subtilis subtilisins (EC 3.4.21.14) (22).

On the basis of the results reported here, it is apparent that strain CIP 82.01 of $V$. alginolyticus and strain I.029, which was originally designated "A. iophagus," are closely related organisms and belong to the same species $(V$. alginolyticus). Nevertheless, differences in the collagenases produced by these two strains indicate that the organisms are not identical. Therefore, we suggest the name Vibrio alginolyticus chemovar iophagus for strain I.029 and the name iophagus collagenase for the corresponding enzyme.

\section{ACKNOWLEDGMENTS}

This work was supported by grant 80.7.0147 from the DGRST and partially by Fondation Francaise pour la Recherche Medicale

We thank V. Keil-Dlouha for providing purified collagenase antibodies. We are also grateful to A. Vincent and D. Leduc for immunochemical analyses and to R. Nageotte for testing endonuclease specificity.

\section{LITERATURE CITED}

1. Ames, G. F. L. 1974. Resolution of bacterial proteins by polyacrylamide gel electrophoresis on slabs. J. Biol. Chem. 249:634-644.

2. Benson, J. R., and P. E. Hare. 1975. o-Phthalaldehyde: fluorogenic detection of primary amines in the picomole range. Comparison with fluorescamine and ninhydrin. Proc. Natl. Acad. Sci. U.S.A. 72:619-622.

3. Emod, I., N. T. Tong, and B. Keil. 1981. Chemical characterization of the homogeneous collagenase from Clostridium histolyticum. Biochim. Biophys. Acta 659:283-291.

4. Gilles, A.-M., and B. Keil. 1976. Cleavage of b-casein by collagenases from Achromobacter iophagus and Clostridium histolyticum. FEBS Lett. 65:369-372.

5. Grabar, P., and C. A. Williams. 1955. Methode immunoelectrophoretique d'analyse de melanges de substances antigeniques. Biochem. Biophys. Acta 17:67-74.

6. Heindl, M.-C., S. Fermandjian, and B. Keil. 1980. Circular dichroism comparative studies of two bacterial collagenases and thermolysin. Biochim. Biophys. Acta 624:5159 . 
7. Herry, P., and V. Keil-Dlouha. 1978. Inhibition of Achromobacter collagenase by bromoacetone and by zinc ions. FEBS Lett. 95:65-69.

8. Hubbard, A. L., and Z. A. Cohn. 1972. The enzymatic iodination of the red cell membrane. J. Cell Biol. 55:390405 .

9. Keay, L. 1969. Neutral proteases of the genus Bacillus. Biochim. Biophys. Res. Commun. 36:257-271.

10. Keil, B. 1979. Some newly characterized collagenases from procaryotes and lower eucaryotes. Mol. Cell. Biochem. 23:87-108.

11. Keil, B., A.-M. Gilles, A. Lecroisey, N. Hurion, and N.-T. Tong. 1975. Specificity of collagenase from Achromobacter iophagus. FEBS Lett. 56:292-296.

12. Keil-Dlouha, V. 1976. Chemical characterization and study of the autodigestion of pure collagenase from Achromobacter iophagus. Biochim. Biophys. Acta 429:239-305.

13. Keil-Dlouha, V., I. Emod, P. Soubigou, L. K. Bagilet, and B. Keil. 1983. Cell-surface collagen-binding protein in the procaryote Achromobacter iophagus. Biochim. Biophys. Acta 727:115-121.

14. Keil-Dlouha, V., and B. Keil. 1978. Subunit structure of Achromobacter collagenase. Biochim. Biophys. Acta 522:218-228.

15. Keil-Dlouha, V., R. Misrahi, and B. Keil. 1976. The induction of collagenase and a neutral proteinase by their high molecular weight substrates in Achromobacter iophagus. J. Mol. Biol. 107:293-305.

16. Kono, T. 1968. Purification and partial characterization of collagenolytic enzymes from Clostridium histolyticum. Biochemistry 7:1106-1114.

17. Kuntiz, M. 1950. Crystalline desoxyribonuclease. J. Gen. Physiol. 33:349-362.

18. Laskowski, M. 1955. Determination of activity by the casein digestion method. Methods Enzymol. 2:32-36.

19. Lecroisey, A., and B. Keil. 1979. Difference in the degradation of native collagen by two microbial collagenases. Biochem. J. 179:53-58.

20. Lecroisey, A., V. Keil-Dlouha, D. R. Woods, D. Perrin, and B. Keil. 1975. Purification, stability and inhibition of the collagenase from Achromobacter iophagus. FEBS Lett. 59:167-172.

21. Long, S., M. A. Mothibeli, F. T. Robb, and D. R. Woods. 1981. Regulation of an extracellular protease and HUT enzymes by histidine in a collagenolytic Vibrio alginolyticus strain. J. Gen. Microbiol. 127:139-145.
22. Markland, F. S., and E. L. Smith. 1971. Subtilisins: primary structure, chemical and physical properties, p. 562608. In P. D. Boyer (ed.), The enzymes, vol. 3, 3rd ed. Academic Press, Inc., New York.

23. Merkel, J. R., J. H. Dreisbach, and H. B. Ziegler. 1975. Collagenolytic activity of some marine bacteria. Appl. Microbiol. 29:145-151.

24. O'Farrell, P. H. 1975. High resolution two-dimensional electrophoresis of proteins. J. Biol. Chem. 230:4007-4021.

25. Ouchterlony, O. 1949. Antigen-antibody reactions in gels. Ark. Kemi Mineral Geol. 26B:1-9.

26. Reid, G. C., F. T. Robb, and D. R. Woods. 1978. Regulation of extracellular collagenase production in Achromobacter iophagus. J. Gen. Microbiol. 109:149-154.

27. Reid, G. C., D. R. Woods, and F. T. Robb. 1980. Peptone induction and rifampin-insensitive collagenase production by Vibrio alginolyticus. J. Bacteriol. 142:447-454.

28. Richard, C., and M. Lhuillier. 1977. Vibrio parahaemolyticus et vibrions halophiles; leur importance en pathologie humaine et dans l'environnement marin. Bull. Inst. Pasteur Paris 75:345-368.

29. Robbertse, P. J., D. R. Woods, A. M. Reay, and F. T. Robb. 1978. Simple and sensitive procedure for screening collagenolytic bacteria and the isolation of collagenase mutants. J. Gen. Microbiol. 106:373-376.

30. Svensson, B., O. Siffert, and B. Keil. 1975. Inhibition of collagenase from Achromobacter iophagus by synthetic peptides. Eur. J. Biochem. 60:423-425.

31. Tanaka, S., and S. Iuchi. 1971. Induction and repression of an extracellular proteinase in Vibrio parahuemolyticus. Biken J. 14:81-96.

32. Titani, K., M. A. Hermodson, L. H. Ericsson, K. A. Walsh, and H. Neurath. 1972. Amino acid sequence of thermolysin. Nature (London) New Biol. 238:35-37.

33. Trocheris, I., P. Herry, V. Keil-Dlouha, and B. Keil. 1980. Chemical modifications of Achromobacter collagenase and their influence on the enzymic activity. Biochim. Biophys. Acta 615:436-448.

34. Welton, R. L., and D. R. Woods. 1973. Halotolerant collagenolytic activity of Achromobacter iophagus. J. Gen. Microbiol. 75:191-196.

35. Welton, R. L., and D. R. Woods. 1975. Collagenase production by Achromobacter iophagus. Biochim. Biophys. Acta 384:228-234.

36. Wünsch, E., and H. G. Heidrich. 1963. Zur quantitativen Bestimmung der Kollagenase. Hoppe-Seyler's Z. Physiol. Chem. 333:149-151. 